\title{
Metal Craft Studio Development: An Idea to Prepare a Teaching Factory Education Concept Model in the Craft Education Study Program, Yogyakarta State University
}

DOI: https://doi.org/10.47175/rielsj.v2i3.302

\author{
| Iswahyudi | \\ Faculty of Language and Arts, \\ Yogyakarta State University, \\ Yogyakarta, Indonesia \\ *iswahyudi@uny.ac.id
}

\begin{abstract}
This study aims to prepare a model for the development of a metal craft practice studio which includes space, equipment, maintenance and occupational safety and health. This study uses a qualitative method with research locations in the metal craft studio at P4TK, Vocational High School 5 Yogyakarta, BRTPD Bantul, and the Indonesian Institute of the Arts Surakarta. Research time March-July 2018. Research instruments are interview, observation, and documentation guidelines. The validity of the data used the validity of interview data, observation, and documentation. Data analysis of data collection, data display, data reduction, and drawing conclusions. The expected result of the research is the realization of a Craft Education studio that is representative and relevant to the world of vocational education and the world of the craft industry. The development of Kriya educational studios refers to existing studios in training institutions and vocational schools. The expected product is the formulation of the Craft Education studio as a studio learning guide. The realization of a studio arrangement that makes it easy for users to produce and manage craft studios. The results of this studio research are expected to be used for the development of the Craft Education studio, Faculty of Language and Arts, Yogyakarta State University.

KEYWORDS

model; development; studio; craft; metal; Yogyakarta State University
\end{abstract}

\section{INTRODUCTION}

Full human development efforts are still emphasized through educational institutions. One of the goals is to create a skilled society or in the previous period the term Hastakarya was often heard. The craft education study program is one of the institutions that are obliged to handle this authority. The formation category includes vocational education that offers a variety of craft skills. This type of education in Western countries has long emerged in line with the rise of scholarship theory, which emphasizes technical and craftmanship aspects. Further developments, especially after the Industrial Revolution period, have supported the development of vocational education towards the industrial world. This phenomenon is still valid today, so that the challenge of higher education in craft education must also refer to the concept of the teaching factory. Mainly in line with the development of Vocational Education where skilled teacher candidates are needed and are able to meet the demands of certain competencies. This is in accordance with the characteristics of vocational education, namely that a close relationship with the world of work is the key to the success of vocational education and the focus of vocational education is emphasized on mastering 
the knowledge, skills, attitudes and values needed by the world of work (Djojonegoro, 1998: 38). In this regard, an adequate craft studio or laboratory becomes a meeting point so that what is learned in educational institutions is in accordance with industry or employment. This is what distinguishes the purpose of Vocational Education with General Education. Vocational education is required as a forum for the formation of students who have good soft skills, hard skills and entrepreneurship.

The Craft Study Program is expected to be able to improve the quality of the superior and competent learning process, especially in the field of practice. The competencies that students acquire during learning can be put into practice as optimally as possible in the workshop. However, in the process of implementing learning, there is often a discrepancy between the theory obtained and the practical process carried out in the studio. Even the results that have been studied on campus both in theory and practice are different from the conditions that exist in the world of work. In general, craft studios in formal education have not met the requirements for industry-appropriate competency training.

The problem that occurs in several vocational schools or art colleges is the lack of facilities and infrastructure for practice studios and their management. This affects the quality of the implementation of the practical learning process carried out. The availability of adequate practical facilities and infrastructure can help students achieve work competence. This is reinforced by the view that the effectiveness of the learning process in an "in door" laboratory is highly dependent on the facilities available in it (Djohar, 2006: 105). In line with what was stated by Charles Prosser, that effective vocational education can only be provided where training tasks are carried out in the same way, tools, machines as those specified in the workplace (Djojonegoro, 1998: 38).

The work studio is one of the means of craft education that serves as a place to practice and develop a person's psychomotor skills who will explore a particular skill. Included in this case, the craft studio, if viewed from the formation of learning characters, is that it can be equated with a workshop or laboratory (Their, 1970). Any vocational education certainly requires equipment that is specific to each type of vocational field. Such education will be successful and satisfactory if appropriate practical equipment is provided, so that theoretical learning will not be able to support (Storm, 1995). This means that in order to instill a competency, students must be educated close to the real conditions or the actual environment as in the workplace, so that the craft studio and its contents must really meet the requirements of practical learning.

One of the functions of the work studio is as a learning practicum facility, where there will be changes in individual behavior as a result of interaction. Based on the behavioral perspective, learning can be illustrated as an observable change in behavior (Orlich, et al., 2007). If so, the work studio is a place for implementing practical learning, on the other hand, learning theory. As it should be noted, the cognitive domain includes related goals or outcomes including memory, knowledge recognition, intellectual ability and skill development. In this case, one cannot master theory well without practice, on the other hand one cannot carry out practice effectively without a good understanding of theory. In line with this, Finc \& Crunkilton said that learning in personality development is not only limited to classrooms or student work studios, but also must be able to develop skills and abilities through various learning activities (Finc \& Crunkilton, 1999).

A studio workshop equipment or infrastructure is always experiencing a decrease in efficiency, availability and reliability as well as the quality of its performance causing the situation to be bad, in line with the duration of use or the influence of age. This will lead to progress for the company. Therefore, every educational institution that organizes studios will try to make the practical equipment function properly, so that the production process 
runs smoothly. Maintenance management is always related to reliability which is always related to failure, because even though a system or component has been designed, manufactured, and operated correctly by involving engineering and control aspects as well as into a maintenance program, generally the higher the repair activity in a system, the need for management and management control into a program of care. In general, the higher the improvement activity in a system, the need for and control in maintenance becomes increasingly important. The main purpose of the maintenance system is to keep the production process in optimum condition. In this case, optimum means the basis for fulfilling the care received by taking into account the minimization of the required costs.

One of the main aspects in terms of placing the equipment factor in this research is to support teaching factory-based learning. Teaching factory is a learning concept in a real situation because it is to bridge the competency gap between the knowledge given in schools and industrial needs (Kuswantoro, 2014). By utilizing the production unit as one of the results of its development. This application can be a learning innovation in schools for competency development of prospective teachers and students, so that the teaching factory must involve partner industries. Indications of teaching factory-based studio equipment are related to equipment, tool use management, maintenance management, repair and calibration (MRC), and layout workshops (Tamrin Kasman et al., 2017).

Starting from the description above, this research is based on the awareness of the weakness of learning facilities and infrastructure in the Metal Craft practice studio-UNY which is categorized as a Pre-Teaching factory condition. Therefore, the problem in this research is formulated as follows:

1. Why is it important to follow up the model for developing a metal craft education practice studio?

2. How is the ideal metal craft studio development model related to learning?

In relation to the realization of ideal and sustainable results, the focus of this research is limited to the development of metal craft studios, with the hope of preparing the realization of the Teaching Factory educational concept. This research is conducted by conducting field studies in educational institutions as partners, namely at SMK 5 Yogyakarta, P4Tk Yogyakarta, BRTPD Pundong Bantul, and the Indonesian Institute of the Arts Surakarta.

The purpose of this study was directed to describe the urgency of developing a metal craft practice studio in the craft education study program at the Yogyakarta State University in order to improve the quality of education. Then formulate a development model in the metal craft practice studio at the Yogyakarta State University craft education study program.

\section{LITERATURE REVIEW}

The model in the Indonesian dictionary can be interpreted, reference, example, polka, and variety (KBBI, 1983:653). However, what is meant in this case is a variety of learning models to be associated with the development method. Learning model is a learning activity designed or developed using certain learning patterns. The learning pattern in question can describe the activities of instructors and students in realizing learning conditions or environmental systems that cause the learning process to occur. Learning patterns explain the characteristics of a series of activities carried out by student instructors (DPSMK, 2008:21).

The current learning model developed in Indonesia is contained in the Appendix of the Minister of National Education Regulation Number 41 of 2007, concerning process standards. Several alternative learning models that can be developed and used innovatively according to the needs and situations encountered in the study room and to support the 
learning climate they contain are active, creative, effective and fun learning or simply abbreviated as PAKEM (DPSMK, 2008:21). . The definition of teaching factory learning has been running in various countries including Indonesia, so the definition of teaching factory learning is so diverse. The definition of teaching factory seems to depend on the expert who put it forward. Teaching facoiry is production-based learning, which is a process of learning expertise or skills that is designed and implemented based on actual work procedures and standards to produce goods or services in accordance with market or consumer demands. The definition has important points, namely production-based learning, skills and skills learning process, goods and services produced meet industry standards and products in accordance with market demands (Purba, 2009).

Production-based learning in the previous paradigm was only prioritizing the quality of products, both goods and services, but the results of the production were not used or based on production starting in the teaching and learning process. Production-based learning in the current paradigm is required to be able to produce goods or services that can be sold or used in society, schools and consumers. Such teaching factory learning is part of production-based learning in the expected new paradigm.

In a simple concept, the teaching factory is a development of the production unit and the development of a dual system education that has often been implemented in various vocational education. The actual concept of the teaching factory is one form of the development of a vocational school into a production school model. Furthermore, Teaching Factory is a learning concept in a real situation because it is to bridge the gap between the knowledge given in schools and the needs of industry (Kuswantoro, 2014). By utilizing the production unit as one of the results of its development. This application can be a learning innovation in schools for competency development of prospective teachers and students, so the teaching factory must involve partners. Indications of teaching factorybased studio equipment are related to equipment, management of tool use, maintenance management, repair and calibration (MRC), and workshop layout (Kasman et al. 2017).

With this, teaching factory learning is more directed to the management process in the study room and practice room based on procedures and standards of work in the industrial world. Furthermore, according to Patricia McQuid, teaching factory learning is; 1 . Produce professional graduates who have advantages in modern industrial concepts and have the ability to work effectively in industry. 2. To improve the use of a curriculum that focuses more on modern industrial concepts. 3. As a means of transferring information technology from partner companies or local companies by making students, project seniors and project teams the main drivers, and 4. As a solution due to the challenges of dynamic technological developments in the industrial world (Mc Quid, 2011).

Practice Studio, is one of the facilities for work practice and study development in an educational institution. According to Law no. 20 of 2003 concerning the National Education System Chapter XII article 45, is to provide facilities and infrastructure for each educational unit, both formal and non-formal, to meet educational needs in accordance with the growth and development of physical potential, intellectual, social, emotional intelligence, and the obligations of students. The provisions in article 45 above clearly the government of the Republic of Indonesia number 19 of 2005 concerning national education standards in Chapter VII of the standard of facilities and infrastructure, article 32, states that every educational unit must have facilities and which include furniture, educational equipment, media, books and resources. other learning materials, consumables and equipment needed to support an orderly and continuous learning process.

Starting from the importance of the practice studio factor, it is related to learning equipment which is so expensive that there must be standardization efforts in its 
supervisory management. Included in this are maintenance methods, neat arrangement and guaranteed work safety as well as various health factors in the work studio.

DEVELOPMENT MODEL OF METAL WORK PRACTICAL STUDIO EDUCATION

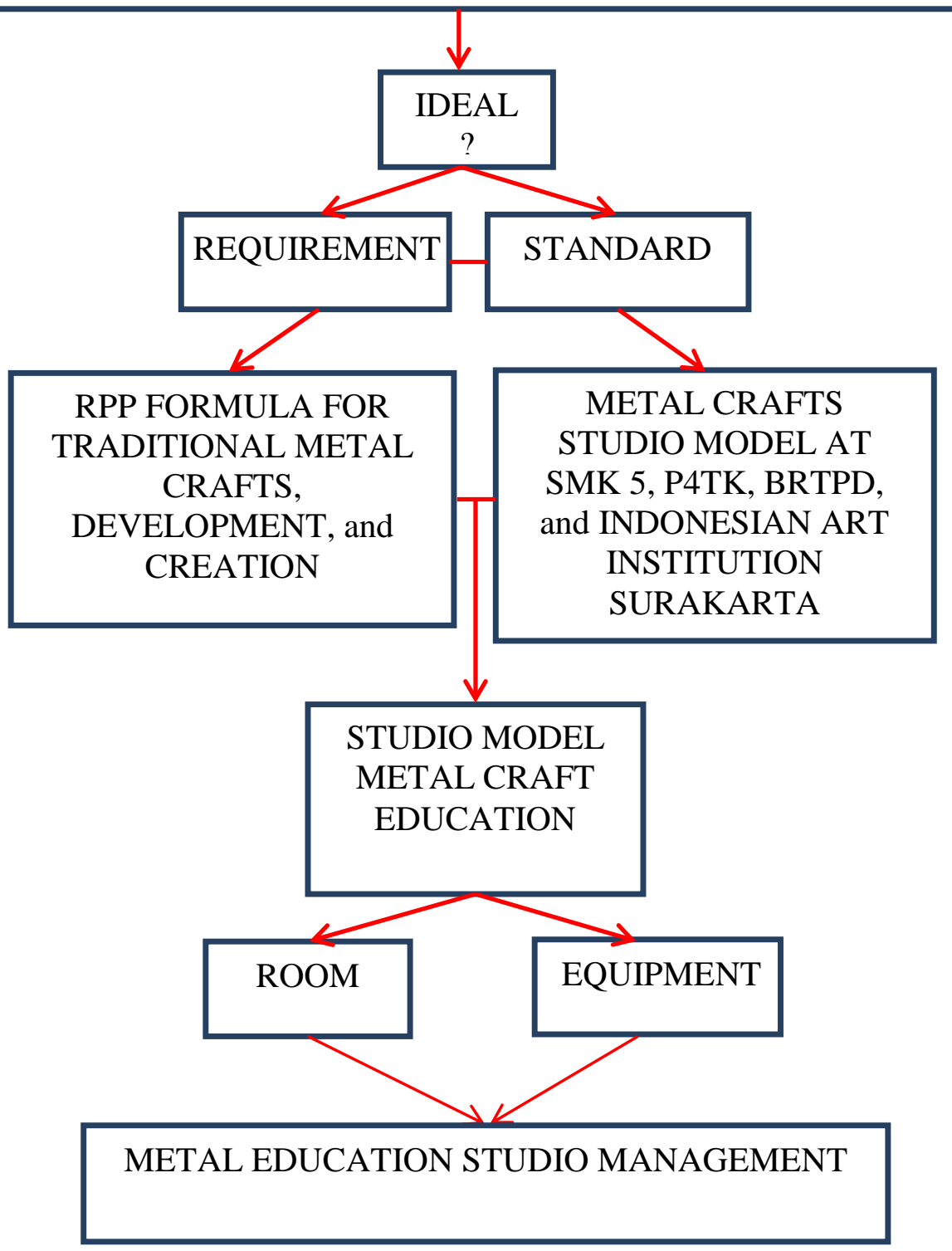

\section{RESEARCH METHODS}

The method used in this research is descriptive qualitative comparative. This kind of research has a purpose, including knowing certain physical developments or the frequency of occurrence of certain aspects of social phenomena, and can also be aimed at solving problems that exist in the present (Bailey, 1978:3-9). This research is humbly an idea to develop a metal craft practice studio related to the rise of the concept of teaching factory education, especially in the Craft Education study program, Faculty of Language and Arts, Yogyakarta State University. The research subjects include: lecturers, heads of practice studios, and toolman or technicians of metal craft practice studios at partner craft education institutions, Yogyakarta State University. The research was conducted in the even semester 
of the 2017/2018 academic year at the Arts and Crafts Education study program, Yogyakarta 5 Vocational High School, and P4TK Yogyakarta, BRTPD Pundong Bantul, and the Indonesian Arts Institute Surakarta within 5 months.

This study uses data collection techniques documentation, observation, and interviews. The documentation method is used to collect written documents for reference sources to be documented as reference material for making models. Observations used participant observation. Focused observations to obtain models from various places to be documented. The interview method used to obtain in-depth information from informants was carried out openly aimed at the actors involved in management, functions and so on.

In relation to the data, it is targeting all equipment in the Arts and Crafts Education study program by making comparisons at study partners, namely at SMK 5 Yogyakarta and P4TK Yogyakarta. Related to data validation because it involves an ideal picture to realize a practice studio that meets the teaching factory standards, it requires informants who meet accountability, so interview techniques and guidelines are needed. Interview is a data collection technique which is done by giving a set of questions both written and recorded (Sugiyono, 2008:199).

The actions taken are through the stages of observation, investigation and comparative analysis. In the observation stage, in this case the researcher identified all the equipment in the metal craft studio of the Arts and Crafts Education study program, to predict its effective ability in learning. At the investigation stage, it is necessary to record in detail all types of equipment for learning metal crafts in the Arts and Crafts Education Study program. Continuing on the comparative analysis stage, is to look at the equipment studios at the bestari partner places, namely at Vocational High School 5 Yogyakarta and P4TK Yogyakarta with consideration in these two partner places that all equipment is considered to have met the teaching factory. Then as research work, is to analyze some studio equipment needed for the development of studies that are synchronized with the curriculum in the Arts and Crafts Education study program. The data analysis technique uses descriptive analysis.

In addition, researchers are also looking for literature reviews related to the maintenance of work studio equipment and theories about the teaching factory. In the observation stage, it is still possible to observe as much as possible in the metal craft work studio room in the Arts and Crafts Education study program. In this stage, it can be done by formulating research objectives and indicating studio equipment in the Arts and Crafts Education study program. Then in the investigation, a description of a construct or construct in this study will be obtained. With the consideration that the partner institutions are also consulted as far as the empowerment of work practice studios in relation to teaching factory education. At this stage, it is also at the same time conducting an evaluation, with temporary results comparing learning facilities in the field of work practice studios that are categorized as pre-teaching factories, namely in the Arts and Crafts Education Study Program with the teaching factory, namely at Vocational High School 5 Yogyakarta and P4TK Yogyakarta. Then in the final stage is to analyze each icon of metal craft studio equipment, with the hope for development in subsequent studies of tests related to these problems.

\section{RESULTS AND DISCUSSION}

\section{Metal Craft Practice Studio Development Model}

Metal Craft Learning Conditions in Craft Education-Yogyakarta State University

Arts and Crafts Education or Craft Education is one of the study programs in the Department of Fine Arts Education and is under the auspices of the Faculty of Language and Arts, Yogyakarta State University. Its vision is to produce qualified and professional 
craft educators who are based on piety, intelligence, and independence. Continuing with its mission, is to provide education and learning based on the achievement of competency standards to produce qualified and competitive teacher candidates. Carry out research for the development of science, art and technology oriented to the creation of crafts. In addition, it also carries out community service by disseminating research results, applying technology and developing craft designs (Kurikulum 2014 Berbasis KKNI Pendidikan Kriya, 2015: 2-3).

Related to the purpose of the arts and crafts education study program is to produce qualified craft educators capable of developing craft learning in vocational high schools and public schools. Besides that, it also educates as prospective craft teachers who have the ability as craft researchers in the context of developing and preserving Nusantara crafts in the community.

The Metal Craft course is a course that teaches the theory and skills of metal work creation and its learning at school. As a course that is categorized as MKBK (Skill-Based Course), this course is taken by craft education students for three semesters in three stages, namely: Metal Crafts I, II, and III. Metal Craft I course with code SSK 6325 is taken in semester 4 with a total of 3 credits, Metal Craft II with code SSK 6426 is taken in semester 5 with a total of 4 credits, and Metal Craft III with code SSK 6433 is taken in semester 6. So for students Those who study metal craft either through TAKS (Final Task of Art) and TAS (Final Task of Thesis) get a total of 11 credits of metal craft practice courses out of 144 credits taken for undergraduate studies in Arts and Crafts Education at the Faculty of Language and Arts, State University of Yogyakarta. The descriptions of the courses and the learning outcomes of the courses can be explained as follows:

\section{a. Description and Learning Outcomes of Metal Craft Course 1}

The Metal Craft I course is oriented towards mastering knowledge and engineering in the creation of works using wudulan or metal carving techniques. Lecture materials include field studies, concept generation, design making, work practices and report generation. The load of 3 credits in this practical course invites students to work on metal in the form of long objects measuring $30 \mathrm{~cm} \times 30 \mathrm{~cm}$ and functional objects measuring $25 \mathrm{~cm} \times 25 \mathrm{~cm} \times 25 \mathrm{~cm}$. Teaching and learning activities are carried out with theoretical and practical lectures. Specifically, the learning outcomes of the Metal Crafts 1 course include aspects of attitude, aspects of knowledge and aspects of skills.

The orientation of learning in the Craft Education study program is directed as prospective teachers who have character as the vision of the Yogyakarta State University. So that the learning demands on the metal craft course 1 must also be able to accommodate learning outcomes about attitudes. Details of learning outcomes in the attitude aspect are as follows: 1) Cooperate and have social sensitivity and concern for society and the environment. 2) demonstrate a responsible attitude towards work in the metal craft sector independently. 3) Appreciate and have sensitivity to the existence of noble metal crafts that grow in the community.

Details of learning outcomes in the knowledge aspect are as follows: 1) mastering the theory of making traditional metal crafts based on concept designs. 2) Mastering the theory of metal carving techniques correctly. 3) Mastering the theory of properties and types of materials used. 4) Mastering the theory of finishing various kinds of metals. Details of learning outcomes in the skills aspect are as follows: 1) Able to produce display objects and functional objects according to the concept design. 2) Able to produce metal crafts using the wudulan technique. 3) Able to finish metal crafts 
according to the concept design. 4) Produce long objects with a size of $30 \mathrm{~cm}$ x $30 \mathrm{~cm}$ and functional objects with a size of $25 \mathrm{~cm} \times 25 \mathrm{~cm} \times 25 \mathrm{~cm}$.

\section{b. Description and Learning Outcomes of Metal Craft Course II}

Metal Craft II course is a continuation of Metal Craft I. This course provides students with the ability to understand the process of developing metal crafts using the filigree technique. The studio practice in this course produces metal crafts in the form of ornamental ornaments and accessories. Lecture material covers concept creation, design and practice of creating prototypes. Evaluation is carried out at the end of the lecture through presentation of work and reports. Teaching and learning activities are carried out with theoretical and practical lectures.

Specifically, the learning achievements of the Metal Crafts 1 course are in the attitude aspects as follows: 1) Cooperating and having social sensitivity and concern for society and the environment. 2) Demonstrate a responsible attitude towards work in the metal craft sector independently. 3) Appreciate and have sensitivity to the existence of adhiluhung metal craft works that are growing in the community. 4) Appreciate and show a responsible attitude towards the superior metal works of each region. Details of learning achievements in the knowledge aspect are as follows: 1) Mastering, understanding and being able to explain well about the development of traditional and modern metal crafts (accessories). 2) Mastering writing or drafting as well as reports according to the guidelines for making the Final Project. Details of learning outcomes in the skills aspect are as follows: 1) Able to produce designs and development prototypes according to the concept. 2) Produce metal crafts in the form of ornamental ornaments and accessories.

\section{c. Description and Learning Outcomes of Metal Craft Course III}

Description of the Metal Craft III course, is a continuation of Metal Craft I and II. Taken by students who are specialized in the craft of metal craftsmanship. This course invites students to optimize their creativity through creating metal crafts into functional or non-functional objects independently according to the choice of raw materials, techniques and designs of each student. Evaluation is carried out at the end of the lecture through presentations of work (joint exhibitions) and reports. Teaching and learning activities are carried out with theoretical and practical lectures. Learning achievement in Metal Craft III in the attitude aspect is still the same as in learning achievement in Metal Craft I and II courses. Meanwhile, in the aspect of knowledge, students are directed to be able to master and be able to explain well about the theory of creative metal craft creation, both orally and in a work report in accordance with the guidelines for writing the Final Project (TAKS). As for the achievement of learning skills, students are directed to be able to produce creative metal crafts into functional or non-functional metal crafts according to the concept.

Table 1. Details of lecture activities for metal craft courses I, II, and III in 1 Semester

\begin{tabular}{|l|l|l|l|l|}
\hline No & Meeting & $\begin{array}{l}\text { Study Outcomes of } \\
\text { Metal Crafts I }\end{array}$ & $\begin{array}{l}\text { Study Outcomes of } \\
\text { Metal Crafts II }\end{array}$ & $\begin{array}{l}\text { Study Outcomes of } \\
\text { Metal Crafts III }\end{array}$ \\
\hline 1 & $3-4$ & - Basic technique & - Sketching new & - Creating basic \\
& & - Forming & motifs & metal craft \\
techniques \\
\end{tabular}




\begin{tabular}{|c|c|c|c|c|}
\hline & & & & $\begin{array}{l}\text { - Development of } \\
\text { the shape and } \\
\text { finishing of metal } \\
\text { crafts }\end{array}$ \\
\hline 2 & $5-6$ & $\begin{array}{l}\text { - Alternative Sketch } \\
\text { - Design } \\
\text { - Selected Design }\end{array}$ & $\begin{array}{l}\text { - Making working } \\
\text { drawings of non- } \\
\text { functional products } \\
\text { - Make long non- } \\
\text { functional objects }\end{array}$ & $\begin{array}{l}\text { - Creating } \\
\text { alternative } \\
\text { sketches of } \\
\text { functional metal } \\
\text { objects: cupboards, } \\
\text { shelves, tables and } \\
\text { chairs } \\
\text { - Transformation of } \\
\text { selected designs to } \\
\text { metal } \\
\text { craftsmanship } \\
\text { drawings }\end{array}$ \\
\hline 3 & $7-8$ & $\begin{array}{l}\text { - Shop drawing } \\
\text { - Ornament } \\
\text { - Functional Items } \\
\text { - Wudulan technique, } \\
\text { Sodetan, and etching } \\
\text { - Finishing }\end{array}$ & $\begin{array}{l}\text { - Creating } \\
\text { ornamental metal } \\
\text { crafts } \\
\text { - Creating } \\
\text { ornamental shapes } \\
\text { metal plate base } \\
\text { - Skilled in } \\
\text { processing with } \\
\text { wudulan, sodetan, } \\
\text { and etching } \\
\text { techniques }\end{array}$ & $\begin{array}{l}\text { - Create working } \\
\text { drawings from } \\
\text { selected designs of } \\
\text { functional metal } \\
\text { crafts } \\
\text { - Development of } \\
\text { functional metal } \\
\text { craft designs with } \\
\text { practical and } \\
\text { innovative forms }\end{array}$ \\
\hline 4 & $9-10$ & $\begin{array}{l}\text { - Accessory Items } \\
\text { - Alternative Sketch } \\
\text { - Selected Design } \\
\text { - Design Transform }\end{array}$ & $\begin{array}{l}\text { - Accessory craft } \\
\text { design } \\
\text { development } \\
\text { concept } \\
\text { - Make alternative } \\
\text { sketches until you } \\
\text { find an alternative } \\
\text { design } \\
\text { - The results of the } \\
\text { selected design are } \\
\text { made working } \\
\text { drawings }\end{array}$ & $\begin{array}{l}\text { - Create metal } \\
\text { furniture crafts for } \\
\text { the living room } \\
\text { - Finishing metal } \\
\text { works of various } \\
\text { techniques and } \\
\text { materials }\end{array}$ \\
\hline 5 & $11-12$ & $\begin{array}{l}\text { - Pictures of disposable } \\
\text { products } \\
\text { - Creating Accessory } \\
\text { Items } \\
\text { - Finishing }\end{array}$ & $\begin{array}{l}\text { - Making working } \\
\text { drawings of } \\
\text { product and } \\
\text { disposable objects } \\
\text { - Create accessory } \\
\text { items according to } \\
\text { selected designs }\end{array}$ & $\begin{array}{l}\text { - Development of } \\
\text { the basic idea of } \\
\text { metal craft creation } \\
\text { - Alternative } \\
\text { sketches as a } \\
\text { consideration for } \\
\text { determining the } \\
\text { design of the metal } \\
\text { craft work } \\
\text { according to your }\end{array}$ \\
\hline
\end{tabular}




\begin{tabular}{|c|c|c|c|c|}
\hline & & & & $\begin{array}{l}\text { choice } \\
\text { - Make working } \\
\text { drawings of } \\
\text { functional and non- } \\
\text { functional objects } \\
\text { that are appropriate } \\
\text { according to size }\end{array}$ \\
\hline 6 & $13-14$ & $\begin{array}{l}\text { - Making works } \\
\text { according to working } \\
\text { drawings } \\
\text { - Finishing }\end{array}$ & $\begin{array}{l}\text { - Making accessory } \\
\text { items according to } \\
\text { working drawings } \\
\text { - Finishing metal } \\
\text { crafts with various } \\
\text { techniques }\end{array}$ & $\begin{array}{l}\text { - Create free-form } \\
\text { metal crafts } \\
\text { according to } \\
\text { working drawings } \\
\text { - Finishing metal } \\
\text { works with various } \\
\text { techniques and } \\
\text { materials }\end{array}$ \\
\hline 7 & $15-16$ & - Work Presentation & - Work Presentation & - Work Presentation \\
\hline
\end{tabular}

Metal Craft Practice Studio Facilities at Yogyakarta State University Craft Education

The learning achievement of the metal craft course as described above takes place in the Metal Craft Practice Studio measuring 8.6 × 5.6 x 3.5 square meters. Facilities available in the studio include: 5 tables, 16 chairs, 4 lamps, 2 fans, and 1 whiteboard. As for the availability of work equipment that facilitates learning activities, it can be described in the following table:

Table 2. Capabilities of Metal studio practice tools at the Arts and Crafts Education Study Program, FBS, UNY (in the category of Pre-Teaching Factory)

\begin{tabular}{|l|l|l|l|l|l|}
\hline \multirow{2}{*}{ No } & \multirow{2}{*}{ Name of Item } & \multicolumn{2}{|l|}{ Item Identity } & \multirow{2}{*}{ Amount } & \multirow{2}{*}{ Condition } \\
\cline { 3 - 4 } & & Brand/Type & Year & & \\
\hline 1. & Electric iron cutter & Modern M-2470 & 2001 & 1 & Good \\
\hline 2. & Electric iron cutter & Bosch GCO 2000 & 2015 & 1 & Good \\
\hline 3. & Hand electric grinder & Modern M 2360 & 2015 & 2 & Good \\
\hline 4. & Manual Pinch & Record N@ 3 & - & 4 & 3 Damaged \\
\hline 5. & Electric Sitting Grinder & Grindar HL.15 & - & 1 & Damaged \\
\hline 6. & Electric Welding Machine & - & 2001 & 1 & Need Repair \\
\hline 7. & Ken Master & Pes Tolk & 2015 & 2 & Good \\
\hline 8. & Spray Gun & Sagola 472 S & 2015 & 2 & Damaged \\
\hline 9. & Spray Gun & K -3 & 2012 & 1 & Good \\
\hline 10. & Air Brush & Profesional E W. 440 & - & 2 & Good \\
\hline 11. & Medium Hand Soldering & Nakai 100 W & 2015 & 1 & Good \\
\hline 12. & Small Hand Soldering & Samurai KS- 40 R & 2016 & 5 & Good \\
\hline 13. & Fine Hand File & 100 M/ 674 Pon & 2016 & 10 set & - \\
\hline 14. & Manual threshing & Manual Injak & 2016 & 10 set & 2 Damaged \\
\hline 15. & Sledge hammer & Camel Togis & 2016 & 10 & - \\
\hline 16. & Medium Iron Hammer & Stanley STHT 8 & 2016 & 10 & Good \\
\hline 17. & Small Iron Hammer & - & 2016 & 10 & - \\
\hline 18. & Medium Burn & BB : Gas & 2016 & 1 & Good \\
\hline 19. & Little Burn & BB : Gas & 2016 & 1 & Good \\
\hline 20. & Wooden Hammer & Kayu Sawo & 2001 & 10 & Good \\
\hline 21. & Manual Metal Scissors & - & 2016 & 3 & Good \\
\hline & & & & \\
\hline
\end{tabular}




\begin{tabular}{|l|l|l|l|l|l|}
\hline 22. & Plate Metal Scissors & Manual & - & 1 & Damaged \\
\hline 23. & U Plywood Saw & Manual & - & 2 & Good \\
\hline 24. & Hand Electric Drill & Modern & - & 2 & Good \\
\hline 25. & Patar & - & - & 5 & Good \\
\hline 26. & Compressor & Swan & - & 1 & Damaged \\
\hline
\end{tabular}

\section{The Urgency of Developing a Metal Craft Practice Studio at Yogyakarta State University}

The Arts and Crafts Education study program, Faculty of Languages and Arts, Yogyakarta State University, is engaged in preparing educational staff in the craft sector for an education level equivalent to Junior High School and Senior High School or the equivalent. His work, which has been running for more than 30 years, has brought educators to various educational institutions. However, when talking about the state of the practice studio, it looks less well maintained and less able to support the ideal quality of practical learning. Even though the demand for educational products, especially from state-owned universities, remains the desire of the public's anomie, so that labels with the predicate of standardization are needed in the education service industry.

The problem of the lack of infrastructure, which is exacerbated by the weak management of the practice studio, certainly affects the quality of the implementation of practical learning. The availability of adequate practical facilities and infrastructure can help students achieve work competence. This is reinforced by the opinion of Djohar who says that the effectiveness of the learning process in an "in door" laboratory is very dependent on the facilities available in it (Djohar, 2006: 105). This opinion is in line with that expressed by Charles Prosser, namely that effective vocational education can only be provided where training tasks are carried out in the same way, tools, machines as those set out in the workplace (Djojonegoro, 1998: 38). It was further explained that through the teaching factory it was possible to bridge the competency gap between the knowledge provided by the school and the needs of the industry (Kuswantoro, 2014).

Metal craft education teaches about the theory and techniques of working with metal raw materials in the form of functional and non-functional works. The achievement of teaching as well as practice in this area of expertise is closely related to the quality of the studio or workshop used. Given the characteristics of metal materials are hard and the engineering process requires special equipment. Without adequate equipment, the teaching process and work practice activities cannot be maximized. Likewise with the fulfillment of occupational safety and health in carrying out work practices. Therefore, a representative work studio plays an important role in realizing learning based on stundent center learning and outcome base learning.

The practice studio plays an important role as a learning practicum facility, where changes in individual behavior are the result of learning interactions. Learning from a behavioral perspective can be illustrated as an observable change in behavior (Orlich et al., 2007). Facilitated learning in the practice studio can help monitor changes in student behavior towards character building to become disciplined, diligent, and confident. This confirms the importance of a representative practice studio for the learning of Craft students. So that it can contribute to increasing interest in education in the craft education study program as a native Indonesian art science.

Starting from Law No. 2 of 1989 article 11, paragraph 3 and Government Regulation No. 29 of 1990 article 3 paragraph 2, it is revealed that vocational education is obliged to prepare students to work in certain fields professionally. Related to this, the craft skills program at Vocational High Schools is also directed to prepare graduates who can work 
and develop their profession in various types of work in the field of handicrafts such as textiles, wood crafts, leather, ceramics, weaving, and metal (Sudarmi, 1999). :10).

In accordance with developments in the Creative Economy, graduates of the Craft Education Study Program are also expected to contribute to the arts and crafts industry. The achievement of the quality of graduates who can work professionally requires the completeness of a representative practice studio. As a consequence, the cost of educational infrastructure is higher when compared to public schools. Starting from the reality of work studio tools that are adapted to the demands of the complexity of learning outcomes with maximum work, it can be estimated that they are very heavy and cannot support the achievement of teaching factory learning. The weak condition of the tools to support the metal craft practice course can be proven by various complaints from students while working on metal creations who say that all practice equipment facilities and studio rooms are not standard for the learning target (interview with Annisa Perwita Sari, Arif Kurniawan, and Rifki Dwi Sejati on April 3, 2018).

\section{Identification of Problems at the Yogyakarta State University Craft Education Practice Studio}

The reality of learning and the condition of the metal craft practice studio in the Craft education study program shows various problems that must be solved in order to improve the quality of education and the quality of its graduates. Improving the quality of education through studio development must be conceptualized in such a way as to suit the exact needs and dynamics of future developments. Considering the challenges of craft education in the global era, dealing with the characteristics of the millennial generation. Therefore, the concept of developing a practice studio is based on the identification of problems that occur in the metal craft education practice studio and their learning.

The concept of developing a metal craft practice studio cannot be separated from the practical learning formulation that is accommodated in the metal craft course itself. However, when analyzing the description of the metal craft course described above, it seems that it is not in line with the orientation of the graduates of the craft education study program. Considering the specifications of the graduates of the craft education study program as prospective Vocational High School teachers in the field of craft expertise, they require the provision of competencies on various techniques of creating works. Meanwhile, competence in metal craft courses as described above, is limited to studying ablution and filigree techniques.

The limitations of learning in these two competencies are certainly not equipping students according to the demands of prospective teacher competencies. Whereas practical learning at the level of Vocational High School majoring in metal crafts has developed more varied and is supported by the teaching factory learning model. This reality demands the enrichment of competence in metal craft courses so that it is in line with the needs of stakeholders, the development of knowledge and standards of the learning process according to the SNPT article 10 paragraph 2 and article 12 paragraph 1-4. Enrichment of competence in metal craft courses is carried out through the reconstruction of courses that were re-conceptualized so that they become traditional-based metal crafts courses, development and creation.

Competency of Traditional Metal Craft Course. This course teaches the theory and basic technical skills of metal crafts through the creation of works using press etching techniques, and winding techniques. Lecture materials include theory of materials, theory of engineering, engineering demonstrations, simulation of work, making work design concepts, practice of creating works and making reports. The Competency of the Metal 
Craft Course of Development. This course contains the development of techniques as well as the concept of creating metal works with soldering (jewelry) and metal carving techniques. Teaching and learning activities are carried out through theory, field studies, engineering demonstrations, practical simulations and the practice of creating work projects. The evaluation is carried out according to the assessment of attitudes, performance, work performance achievements, presentation of works and reports. In more detail, the following table describes the lecture activities as well as the learning achievements of the three metal courses. Competence of the Creative Metal Craft Course. This course is an elective subject according to the student's interest in pursuing metalworking skills. The lecture material contains engineering enrichment with oxyaccetylin welding techniques and metal casting techniques. Specifically, the orientation of the course is emphasized on optimizing student creativity in exploring the concept of creation, design design, medium, technique, and the process of creating works. Therefore, the achievement of competence is to be able to create a final project of artistic value that is creative, innovative and can be included in the student creativity program.

Table 3. Details of Learning Outcomes in Traditional Metal Craft Courses, Development, and Creation.

\begin{tabular}{|c|c|c|c|}
\hline Number & $\begin{array}{l}\text { Competency of Traditional } \\
\text { Metal Craft Course, } 3 \text { credits } \\
\text { ( } 5 \text { Hours })\end{array}$ & $\begin{array}{l}\text { Metal Development } \\
\text { Course Competencies } \\
4 \text { credits } \\
\text { (6 Hours } 40 \text { Minutes) }\end{array}$ & $\begin{array}{c}\text { Metal Development } \\
\text { Course Competencies } \\
4 \text { credits } \\
\text { (6 Hours } 40 \text { Minutes) }\end{array}$ \\
\hline 1. & $\begin{array}{l}\text { - Knowledge of Materials in } \\
\text { Metal Etching and Press or } \\
\text { Sudet Engraving } \\
\text { techniques, and wire } \\
\text { winding. } \\
\text { - The practice of metal work } \\
\text { design based on the concept } \\
\text { of traditional metal crafts. }\end{array}$ & $\begin{array}{l}\text { - Knowledge of Tools and } \\
\text { Materials in metal } \\
\text { carving and soldering } \\
\text { techniques (Filigri). } \\
\text { - The practice of value- } \\
\text { based metal work design } \\
\text { development into } \\
\text { jewelery and display } \\
\text { products }\end{array}$ & $\begin{array}{l}\text { - Knowledge of Materials } \\
\text { in Welding, Smelting, } \\
\text { and Metal Casting } \\
\text { techniques. } \\
\text { - The practice of metal } \\
\text { work design based on } \\
\text { artistic research and } \\
\text { novelty values. }\end{array}$ \\
\hline 2. & $\begin{array}{l}\text { - Metal plate cutting } \\
\text { techniques. } \\
\text { - Thinking technique. } \\
\text { - Metal etching technique. } \\
\text { - Press or suction carving } \\
\text { technique. } \\
\text { - Twist, twist and knit metal } \\
\text { wire or wire wrap } \\
\text { techniques. } \\
\text { - Finishing techniques with } \\
\text { SN liquid, Polish, and } \\
\text { Coating/ Coating Clear }\end{array}$ & $\begin{array}{l}\text { - Techniques for making } \\
\text { metal carving tools and } \\
\text { materials. } \\
\text { - Techniques for forming } \\
\text { metal plates. } \\
\text { - Metal Carving } \\
\text { Technique } \\
\text { - Metal wire processing } \\
\text { and forming techniques. } \\
\text { - Cut, bend and assemble } \\
\text { techniques. } \\
\text { - Techniques for tin } \\
\text { soldering, haris soldering } \\
\text { and brass soldering. } \\
\text { - Polishing and } \\
\text { electroplating finishing } \\
\text { techniques }\end{array}$ & $\begin{array}{l}\text { - Forging Techniques } \\
\text { - Enrichment of metal } \\
\text { joining techniques with } \\
\text { acetylene welding } \\
\text { techniques. } \\
\text { - Metal smelting } \\
\text { techniques. } \\
\text { - Metal casting technique. } \\
\text { - Deepening of metal } \\
\text { decoration techniques. } \\
\text { - Exploration of } \\
\text { finishing techniques and } \\
\text { presentation of metal } \\
\text { works }\end{array}$ \\
\hline
\end{tabular}




\section{Identify the problem of the metal craft practice room and studio tools}

Identification of problems in the metal craft practice studio can be detailed as follows:

1. The location of the studio adjacent to the Gallery and the Academic Service Center Building is deemed inappropriate because the impact of metal work produces a noisy sound. Likewise, the activity of burning metal and its supporting materials, which produces smoke as well as a pungent aroma in the studio room and spreads to other rooms.

2. The room size is less spacious (8.6x5.6 square meters) for the needs of a metalworking studio with a capacity of 15 people per class. So it is not adequate for metal work that requires a wide range of motion. One room is used for various techniques.

3. Air circulation in the room is not smooth, as evidenced by air pollution in the practice of desoldering, burning metal and etching which still smells, even though the room has not been used within 1 week.

4. The size of the table is not thick enough as the basis for the metal carving technique process so that the sound during the process sounds too noisy and noisy. Likewise, the quality of the chair is less ergonomic.

5. Does not have a table that can specifically be used for teaching soldering competence.

6. There was damage to a number of equipment which was neglected without any attempt to repair.

7. The availability of specifications and the number of work equipment does not support practical learning and the achievement of competency standards.

8. Weak management of security and maintenance of practice studios. There is only one employee who doubles as a technician, warehouse keeper, and manager of tools for 2 craft and fine arts study programs.

9. There is no standard operating procedure manual for the use of work equipment.

10. The supporting equipment for occupational safety and health is not yet available.

\section{Formulation of Criteria for Metal Craft Practice Studio Room at Yogyakarta State University}

The quality of the room will certainly be able to encourage students' enthusiasm for learning in the practice of creative works. In order to encourage freedom of movement in the room when practicing crafts, the size of a metal craft studio which is comparable to a capacity of 15 students is $15 \times 8$ square meters. This is considering the need for practical learning space to use a number of equipment and infrastructure in the form of tables and chairs. The size of the room that is proportional to the capacity of its users certainly facilitates supervision in guiding student performance to achieve competency standards.

Likewise with the availability of standard tables and chairs used in metal workspaces. There is a prerequisite that the workbench for the metal carving process must be at least 3 $\mathrm{cm}$ thick. The goal is that the engraving process on the workpiece becomes focused because the thickness of the table is able to reduce vibration and noise due to the hammer and chisel work process. In addition, the quality factor of a sturdy chair, and in accordance with human proportions can support concentration as well as the comfort of the work process.

Specifically, in the desoldering practice which is directed at the competence to make jewelry products, a technical and private work desk is needed to support concentration. Considering that in this study, you are working on small metal works, where the embodiment is composed of components that are also small in size. So the jewelry 
workbench must be able to support accuracy in desoldering, cutting, forming, storing jewelry tools, and accommodating metal scraps in the form of powder.

\section{Formulation of Criteria for Metal Craft Practice Equipment}

The ideal practice studio is determined by the availability and capability of equipment to facilitate learning. As far as the investigation has been carried out, there is no standard that regulates the standard of equipment in metal craft work studios. However, based on a review of metal craft studios at P4TK, Vocational High School 5 and BRTPD Yogyakarta, it shows that there is a strengthening of work equipment facilities for carving, soldering and jewelry competencies. Meanwhile, based on the results of a review of the metal studio at the Indonesian Institute of the Arts, Surakarta, it shows the facilitation of equipment for competence in metal carving, kethok formation, and forging traditional weapons. tra The search for metal craft studios in the realm of education is carried out by referring to practice studios in educational institutions at the Vocational High School and P4TK levels. The formulation of the equipment needed in the practice of metal crafts, is based on the competency standards taught. The explanation is as follows:

\section{Forging technique}

The forging technique is intended to form metal materials by pounding metal materials using a hammer to fit the planned shape. Equipment requirements in this technique refer to two types of forging techniques, namely hot forging and cold forging. In hot forging, metal formation is carried out by heating so that the metal material is softer and easier to shape. The necessary facilities are a furnace, charcoal, blower, iron anvil, clamping pliers, and an iron hammer. In learning in the craft study program, the use of forgings is directed to the need to form work equipment such as making carving chisels in the practice of carving competence.

As for cold forging, it is a forging technique that is carried out to form metal without being heated. The application of this technique in learning is directed at flattening, concave, convex and riveting metal plates. The equipment needed is a concave wooden base, rubber hammer, wooden hammer, iron hammer, iron anvil.

\section{Carving Technique}

Metal crafts made by carving techniques are the creation of works using metal materials that are carved for the manufacture of ornaments and ornaments. In carving techniques can be categorized into:

a. Etching technique in the special sense of etching is painting, engraving or transferring an image onto a metal surface. This is done by scraping the metal surface using a chemical acid solution. There are two types of etching results in the etching process. First, positive etching, where the motif (can be an image or text) stands out. This happens because the original metal surface is allowed to emerge, so that the low background or base is eroded by the acid solution. Both etchings are negative, that is, the visible motif is sinking or low because it is eroded by acid, so that the metal surface background is higher.

b. The cutting technique or press carving is a carving technique using a carving chisel by scratching and pressing it on a metal plate. This technique usually uses a thin metal material, so that the formation of the hollow is enough to press the chisel and the hand does not hit seriously.

c. Wudulan carving technique, namely the technique of carving metal using jabung as a base for metal workpieces. In this case the metal plate to be carved is placed on 
top of the shell. Then to make the carving basins, metal chisels are used which are beaten with an iron hammer. After making the basin is considered sufficient, then the metal is removed from the shell by heating it then turning it over and placing it back on the shell in the opposite position of the first process. After it can be seen in the form of a protrusion which in this case is a form of decoration or ornament on the surface, it is immediately refined further according to the idealized design.

d. The Krawangan carving technique is a metal carving technique with invisibility. The shape of the decoration that he made was not completely see-through, because only in certain areas or places a hole was made according to the design.

e. Engraving technique is a technique in metal crafts that is placed as a decoration on a metal surface by scratching, cutting, and slashing. In addition, this technique can also be done by carving, especially on massive metal surfaces. From various engraving processes, it will be possible to produce a craft art product with various decorations and ornaments on pure materials.

\section{The soldering technique}

In this case, jewelry can be distinguished from the use technique based on the aspect of the material which is divided into:

a. Filligri

The filligri technique is a jewelry making technique by arranging metal wires of a certain diameter into a metal frame, so that the arrangement of the wires becomes a shape according to the design. In the filling technique, the joining uses a hard solder (silver solder) in the form of a powder. Making solder powder by mixing silver metal and brass metal with a predetermined amount then melted. After the ingredients are mixed, then the solder is cooled. Furthermore, the solder is ready to be made into powder by filing or pounding it using a metal baking sheet.

b. Solid

Solid jewelry technique is a form of jewelry making that takes materials from massive metal. In this case massive metal can be made by forging or grinding to obtain the desired shape and thickness. After the process of forming the jewelry material, then the metal is cut according to the drawing and joined using the soldering technique. Then after the jewelry is assembled, the finishing process is immediately carried out.

\section{Oxyacetylene Welding Technique}

The use of this technique is based on the competence of joining metals using a welding machine. Oxyacetylene welding is a liquid welding process in which heat is obtained from the combustion of a mixture of oxygen and acetylene gas to produce a welding flame. Technically, oxyacetylene welding can be used to join relatively thin to medium thickness materials. The welding method is carried out by heating both parts of the metal surface until it melts and adding additional material from the melted part to make it one.

Mastery of the oxy-acetylene welding technique competence is an engineering enrichment in the metal craft course. In the creation of metal works, this welding technique can be used for the following needs:

a. Melting or mixing metal alloys.

b. Joining metal with solid joint strength so that it can be formed, either by forging or engraving.

c. Making three-dimensional objects through the formation and joining of metal plates. 
The need for oxy-acetylene welding equipment in metal craft practice studios requires a medium-sized type of oxy-acetylene welding equipment and is equipped with a trolley so that it is easy to move according to storage and usage needs. Specifically, there is also the development of oxy-acetylene welding which is suitable for the joining of small and medium-sized metal crafts. This tool is known as the smith torch. Due to the orientation and specifications of metal craft practice, this type of tool is easier and safer to use.

\section{CONCLUSION}

Based on the discussion above, the model for developing a metal craft practice studio can be pursued through the following:

1. Specifications for the practice studio in the metal craft education study program, Yogyakarta State University, directed at small and medium sized work projects.

2. The description and continuity of learning in traditional metal craft RPP, development, and creation become a reference in determining the size of the room, the type and amount of equipment, and its maintenance.

3. Arrange the arrangement of one room in the metal craft studio for three levels of metal craft learning at Yogyakarta State University.

4. Determine basic equipment that is proportional to the number of students and can support the achievement of metal craft work at Yogyakarta State University.

5. Formulate maintenance management of studio space, equipment and safety and health in its use.

6. There needs to be further research on the management of Studio Facilities in relation to building a Characterized Craft education culture.

7. Development of rooms and equipment that has met the needs, needs to be balanced with maintenance efforts so that they are maintained in prime condition. It was explained that maintenance is a systematic control effort in conditioning the studio by means of maintenance and repair so that it always functions properly. This studio maintenance effort is closely related to the extent and how the practice studio operates. The operation of studio equipment that is not based on an understanding of work procedures can endanger the safety of users and the facilities used. Especially on manual equipment whose operation refers to the user. Considering the practice of metal crafts using manual equipment on hardcharacterized materials. The risk of damage to work equipment can be minimized so as not to complicate its maintenance later. Therefore, the operation of equipment and maintenance must be regulated in written rules in the form of rules for the use of practice studios

\section{REFERENCES}

Autio, O. (2016). Traditional craft or technology education: Development of students' technical abilities in Finnish comprehensive school. International Journal of Research in Education and Science (IJRES), 2(1), 75- 84.

Eva Veeber, Erja Syrjäläinen and Ene Lind, A discussion of the necessity of craft education in the 21st century. Techne Series A, 22(1), 15-29

Kuswantoro, Agung (2014). Teaching Factory Rencana dan Nilai Entrepreneurship. Yogyakarta: Graha Ilmu

Buku Petunjuk Fakultas Bahasa dan Seni. (2015). Kurikulum 2014 Berbasis KKNI Pendidikan Kriya 2015. Yogyakarta: FBS, Universitas Negeri Yogyakarta

Depdiknas (2003). Undang-Undang Republik Indonesia Nomor 20 Tahun 2003 Tentang Sistem Pendidikan Nasional. Jakarta: Depdiknas. 
Djohar (2006). Guru, pendidikan dan pembinaanya.(Penerapanya dalamPendidikan dan UU Guru). Yogyakarta:CV. Grafika Indah.

DPSMK (2008). Model-Model Pembelajaran di SMK 2010-2014. Jakarta: Depdiknas

Dadang Hidayat M. (2011). Model pembelajaran Teaching Factory Untuk Meningkatkan Kompetensi Siswa Dalam Mata Pelajaran Produktif. Jurnal IlmuPendidikan, Vol 17, No 4.

Edward. V.W and Andre. D A (1976). Modern Scholl Shop Planning Seventh Edition. Michigan: Prakken Pub. Inc.

Efbeling, Charles. (1997). An Introduction to Reliability and Maintenaanbility Engineering. The MC Graw-Hill Companies, Inc.

Finc \& Crunkilton. (1999). Curriculum Development in Vocational: Planning, Content and Implementation. 5 th Edition. Virginia: Polytechnic Institute \& State University.

Kusuma, Yariad. (2005). Effective Maintenance Management. Jakarta: Pusat Pengembangan Bahan Ajar.

Keznwsnb, Harold. (2001). Project Management a System Approach to Planning Schedullingand Controlling. Prentice Hall.

Orlich, et al. (2007). Teaching Strategies A Guide to Effective Instruction Laboratory. Michigan: Prakken Pubklication, Inc.

Pakpahan, Jorlin. (1994), "Sistem Ganda pada Sekolah Menengah Kejuruan Implementasi Link and Match dalam Upaya Peningkatan Mutu Pendidikan Teknologi dan Kejuruan", dalam Seminar NasionalForum Komunikasi Pendidikan Teknologi dan Kejuruan SeIndonesia, Surabaya: IkIP Surabaya.

Mc.Quid, Patricia et al. (2011). Teaching Factory: Proceedings American Society for Engineering Education. San Luis Obispo, California Polytecnic State University

Poerwodarminto, W.J.S., (1983). Kamus Besar Bahasa Indonesia. Jakarta: Balai Pustaka

Plomp, T. (1997). Educational\& Training System Design: Introduction Universityof Twente Facultyof Education Scienece and Technology. Enschede, the Netherland

Sovia Veronica Purba (2009). Newsletter IGI. Jerman: IGI Consultant for Institusional and Management of Teaching Factory

Storm, G. (1995). Managing the Occupational Education Laboratory. Michigan Prakken Publication.

Sudarmi. (1999). Hubungan Antara Kelengkapan Fasilitas Praktik dan Prestasi Belajar Siswa Dalam Pelaksanaan Pendidikan Sistem Ganda Di SMK 5 Yogyakarta, skripsi tidak diterbitkan. Yogyakarta: IKIP YOGYAKARTA

Tamrin Kasman et al, (2017). Tata Kelola Pelaksanaan Teaching Factory. Jakarta: Direktorat Pembinaan Sekolah Menengah Kejuruan. Dirjend Pendidikan Dasar dan Menengah. Kementrian Pendidikan dan Kebudayaan. Republik Indonesia.

Their, Herbert. D. (1970). Teaching Elementary Scholl Science. A Laboratory Approach. New York: Heath and Comnpany.

Thomas Sukardi. (2008).Pengembangan Model Bengkel Kerja Praktik Sekolah Menengah Kejuruan. Disertasi, tidakditerbitkan, Universitas NegeriYogyakarta: Yogyakarta.

Djojonegoro, Wardiman. (1998). Pengembangan sumber daya manusia melalui Sekolah Menengah Kejuruan (SMK). Jakarta: PT. Jayakarta Agung Offset.

Wisnu Febriyanto. (2016). Paket Keahlian Desain Produksi Kriya Logam SMK Kelompok Kompetensi D. Jakarta: Direktorat Jendral Guru dan Tenaga Kependidikan Kementrian Pendidikan dan Kebudayaan.

Interviewes:

- Muji Rahayu, Widyaswara Studio Kriya Logam P4TK Seni Budaya Yogyakarta 
- Wisnu Febrianto, Teknisi Studio Kriya Logam P4TK Seni Budaya Yogyakarta

- Sri Bandono, Pengajar Kriya Logam di BRTPD Pundong Bantul

- Guru, Kepala Studio, dan Teknisi SMK N 5 Yogyakarta

- Sudarto, Teknisi Studio Kriya Logam ISI Surakarta

Craft Education Students, Interest in Metal Craft Studies:

- Rifki Dwi Sejati

- Muhammad Arif Kurniawan

- Annisa Perwita Sari

- Huzaina

- Agus Rohmatdi

- Zulfi Hafirudin
15207241008

15207241030

15207241032

15207241033

15207241038

15207241043 